\title{
The relationship of mean temperature and 9 collected butterfly species' wingspan as the response of global warming
}

\author{
Sumi $\mathrm{Na}^{1}$, Eunyoung Lee ${ }^{2}$, Hyunjung $\mathrm{Kim}^{1}$, Seiwoong $\mathrm{Choi}^{3}$ and Hoonbok $\mathrm{Yi}^{1,2^{*}}$ (D)
}

\begin{abstract}
Background: Organism body size is a basic characteristic in ecology; it is related to temperature according to temperature-size rule. Butterflies are affected in various aspects by climate change because they are sensitive to temperature. Therefore, this study was conducted to understand the effect of an increase in temperature due to global warming on the wing of butterflies.

Results: A total of 671 butterflies belonging to 9 species were collected from 1990 to 2016 in Seoul (336 specimens) and Mokpo (335 specimens). Consequently, as the mean temperature increased, the wing length of the species increased. However, there are exceptions that the Parnassius stubbendorfii, Pieridae canidia, and Pieris rapae wing length of Seoul increased, but the butterfly wing length of Mokpo decreased.

Conclusions: The positive correlations between the butterfly wing length and mean temperature showed that the change of mean temperature for about 26 years affects the wing length of butterfly species. The exception is deemed to have been influenced by the limited research environment, and further studies are needed. We would expect that it can be provided as basic data for studying effect of climate change.
\end{abstract}

Keywords: Air temperature, Butterfly, Climate change, Length, Lepidoptera, Wing

\section{Introduction}

Global warming caused by climate change is a problem that has been occurring steadily and continuously (IPCC 2013; Stocker 2014). According to RCP scenario, the global mean temperature has risen by $0.85^{\circ} \mathrm{C} / 10$ years from 1880 to 2012 (IPCC 2013) whereas Korea's mean temperature has risen by $0.18{ }^{\circ} \mathrm{C}$ from 1912 to 2017 (NIMS 2018). It is expected that the rate of temperature increase in Korea peninsula will be severe compared to the Earth's global warming (Lee et al. 2011).

Climate change is known to affect biological traits such as animal population density and distribution, body

\footnotetext{
* Correspondence: yih@swu.ac.kr

'Department of Bio and Environmental Technology, Graduate School of Seoul Women's University, Seoul 01797, Republic of Korea

¿Department of Bio and Environmental Technology, Seoul Women's

University, Seoul 01797, Republic of Korea

Full list of author information is available at the end of the article
}

shape and size, reproduction, genetic changes, and extinction of species (IPCC 2007). In general, insects are impacted by temperature increases in terms of phenology, distribution areas, population growth rate, activity period, and increase in number (Kiritani 2006; Parmesan 2007; Trnka et al. 2007).

Organism body size is a fundamental trait in ecology (Calder 1996; Kingsolver and Huey 2008; Peters 1983). Body size is correlated with ecological processes across multiple scales, including disease spreading (Russell et al. 2011), individual fecundity (Honĕk 1993), food web structuring (DeLong et al. 2015; Griffiths 1986), population biology (Siemann et al. 1996; White et al. 2007), and ecosystem services (Baudron et al. 2014; Sheridan and Bickford 2011). Understanding changes in body size thus informs both basic and applied ecological research.

The temperature-size rule (TSR) reports that temperature and body size of an organism are negatively

(c) The Author(s). 2021 Open Access This article is licensed under a Creative Commons Attribution 4.0 International License, which permits use, sharing, adaptation, distribution and reproduction in any medium or format, as long as you give appropriate credit to the original author(s) and the source, provide a link to the Creative Commons licence, and indicate if changes were made. The images or other third party material in this article are included in the article's Creative Commons licence, unless indicated otherwise in a credit line to the material. If material is not included in the article's Creative Commons licence and your intended use is not permitted by statutory regulation or exceeds the permitted use, you will need to obtain permission directly from the copyright holder. To view a copy of this licence, visit http://creativecommons.org/licenses/by/4.0/. 
related (Atkinson 1994). Given the continuing rapid changes in local and global climate, it is important to understand whether the body size changes predicted by the TSR can be extended to wild-capture organisms over long periods of time (Sheridan and Bickford 2011).

Insects are the most flourishing classification of all living creatures on Earth, and it has a variety of habitats and behavior that can serve as an indicator species to notice environmental change (Dingle and Khamala 1972; Lack 1986; Rautenbach et al. 1988). In addition, insects are thermophilic animals and they are sensitive indicators of climate change impacts because their distribution and life cycle are closely related to temperature (Kwon et al. 2008). Tseng et al. (2017) reported that the size of beetles grown in laboratories decreased by $95 \%$ of the body size of larger species and by disproportionately smaller than smaller beetles.

Butterfly, the subject of this study, is a collective name of a group of insects included in Insect Lepidoptera, which are active in the daytime. Taxonomically, the butterfly accounts for 2 superfamilies, 5 families, 23 subfamilies, 124 genus, and 280 species of the Lepidoptera in Korea (Paek and Shin 2010).

Butterflies are particularly sensitive to the functional or spatial changes of ecosystems and landscapes, and so can be used as special indicator species for detecting changes in other insect populations (Jeong et al. 2012). According to a recent study, the distribution pattern of butterflies changes due to the influence of climate change (Jeon 2014). The timing of flight season of Canadian butterflies was sensitive to spring temperatures. Among them, species with shorter flight season and wing size were more related (Kharouba et al. 2014).

In this study, we use butterfly specimens from Seoul Women's University in Nowon-gu, Seoul, and Mokpo University located in Muan-gun, Mokpo-si, Jeollanamdo, to analyze the relationship between the length of butterfly wings and the mean temperature. Also, we selected the butterflies as a model organism group to enhance the possibility of climate indicator species.

\section{Materials and methods}

The 671 pieces of the butterfly specimen were 9 species, which were Lycaenidae (Celastrina argiolus), Nymphalidae (Polygonia c-aureum), Papilionidae (Atrophaneura alcinous, Papilio macilentus, Parnassius stubbendorfii), and Pieridae (Colias erate, Pieris canidia, Pieris dulcinea, Pieris rapae). These were collected at Seoul (336 specimens) and Mokpo (335 specimens) for 26 years from 1990 to 2016 (Table 1).

Specimens whose length was difficult to get data due to damage to the wings or collection date and location were not included. Therefore, a total of 671 samples were used in this study. The identification of the butterfly specimens were conducted in reference of the Coloured Butterfly of Korea (Shin 1991).

Table 1 Analysis of the relationship between mean temperature and butterfly wing length by linear regression analysis $\left({ }^{*} p<0.05\right.$, ${ }^{* *} p<0.01,{ }^{* * *} p<0.001$, wing unit: $\mathrm{cm}$ )

\begin{tabular}{|c|c|c|c|c|c|c|c|c|c|c|}
\hline \multirow[b]{2}{*}{ Family name } & \multirow[b]{2}{*}{ Scientific name } & \multicolumn{2}{|c|}{ Photo } & \multirow[b]{2}{*}{ Year } & \multirow[b]{2}{*}{ Site } & \multirow[b]{2}{*}{$N$} & \multirow[b]{2}{*}{ Fore wing } & \multirow[b]{2}{*}{ p-value } & \multirow[b]{2}{*}{ Hind wing } & \multirow[b]{2}{*}{ p-value } \\
\hline & & Male & Female & & & & & & & \\
\hline \multirow{2}{*}{ Lycaenidae } & \multirow{2}{*}{ Celastrina argiolus } & & & 1995-1999, 2007 & Seoul & 26 & $13.93 \pm 0.31$ & - & $10.66 \pm 0.28$ & . \\
\hline & & & & 2001-2010, 2012, 2015 & Mokpo & 126 & $15.33 \pm 0.15$ & . & $11.58 \pm 0.13$ & . \\
\hline \multirow{2}{*}{ Nymphalidae } & \multirow{2}{*}{ Polygonia c-aureum } & & & 1992,1994-1999 & Seoul & 26 & $27.80 \pm 0.28$ & - & $19.57 \pm 0.32$ & . \\
\hline & & & & $2000-2007,2016$ & Mokpo & 67 & $28.27 \pm 0.23$ & $* * *$ & $20.18 \pm 0.17$ & $* * *$ \\
\hline \multirow{5}{*}{ Papilionidae } & Atrophaneura alcinous & & & 1995-1998 & Seoul & 15 & $43.66 \pm 2.30$ & - & $37.37 \pm 3.25$ & . \\
\hline & \multirow{2}{*}{ Papilio macilentus } & & & 1995-1998 & Seoul & 26 & $52.25 \pm 2.25$ & $* \star \star$ & $51.88 \pm 2.58$ & ** \\
\hline & & & & $2001,2003,2005-2006$ & Mokpo & 9 & $59.18 \pm 2.17$ & - & $65.41 \pm 2.60$ & * \\
\hline & \multirow{2}{*}{ Parnassius stubbendorfii } & & & 1996-1999, 2009 & Seoul & 26 & $32.27 \pm 0.36$ & - & $25.57 \pm 0.37$ & - \\
\hline & & & & 1995, 1997, 2002, 2006 & Mokpo & 18 & $32.07 \pm 0.46$ & * & $24.77 \pm 0.33$ & \\
\hline \multirow{7}{*}{ Pieridae } & Colias erate & & & 1995-1999, 2006, 2009 & Seoul & 29 & $27.00 \pm 0.29$ & - & $19.74 \pm 0.29$ & - \\
\hline & \multirow[t]{2}{*}{ Pieris canidia } & \multirow{2}{*}{ 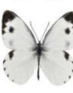 } & & $\begin{array}{c}1995-1999,2003,2006-2007,2009- \\
2010,2013\end{array}$ & Seoul & 52 & $24.18 \pm 0.30$ & - & $17.95 \pm 0.33$ & - \\
\hline & & & & 2001-2007, 2015 & Mokpo & 32 & $25.58 \pm 0.28$ & - & $17.07 \pm 0.27$ & - \\
\hline & & & & & & & & & & \\
\hline & Pieris dulcinea & & & 1996-1999, 2009 & Seoul & 12 & $25.75 \pm 1.18$ & ** & $17.81 \pm 0.93$ & ** \\
\hline & \multirow{2}{*}{ Pieris rapae } & \multirow{2}{*}{ * } & & $\begin{array}{c}1990,1992,1995-1999,2005-2006 \\
2009\end{array}$ & Seoul & 124 & $26.86 \pm 0.21$ & - & $19.82 \pm 0.20$ & - \\
\hline & & & & $2001-2004,2006,2010,2015-2016$ & Mokpo & 83 & $26.06 \pm 0.19$ & - & $18.81 \pm 0.16$ & . \\
\hline
\end{tabular}


Antenna, body, fore, and hind wing lengths were commonly used when measuring the size of the butterfly wings. The items except for the antenna and body lengths were measured by the Vernier calipers (0-150, Ningbo Aiyun Tools Co., Ltd., China). In the case of antenna and body length, the measurement was skipped because it was not perfectly preserved. The length of the fore wings was measured from the starting point of the forelimb base to the end of the seventh vein, and the length of the hind wing was measured from the starting point of the hind wing base to the end of the third vein (Fig. 1).

The mean temperature of collection date and location of specimen was calculated using ASOS (Automated Synoptic Observing System) data of the Meteorological information open portal (https://data.kma.go.kr/cmmn/ main.do). It was measured in the Seoul Weather Observatory in Seoul (latitude, 37.57142; longitude, 126.9658) and Mokpo Regional Meteorological Office in Mokpo (latitude, 34.81732; longitude, 126.38146).

The relationship between the butterfly hind and fore wing lengths and the mean temperature was investigated by using simple linear regression analysis. The SPSS version 24 (SPSS Inc., Chicago, IL, USA) and STATISTICA version 7 (StatSoft Inc., Tulsa, Oklahoma, USA) were used for statistical analysis.

\section{Result}

In case of annual mean temperature, it showed a steady rise over the years in Korea. Also, when comparing the annual mean temperature changes of Seoul and Mokpo, the change of Mokpo is steeper than that in Seoul. The annual mean temperature is as shown in Fig. 2.

As a result of the analysis between mean temperature and butterfly wing lengths, both of the butterfly wing lengths of $C$. argiolus in Lycaenidae increased with increasing mean temperature in Seoul and Mokpo.

The butterfly wing length of $P$. c-aureum in Nymphalidae increased with increasing mean temperature in Seoul and Mokpo. Especially P. c-aureum in Mokpo was significantly increased both of fore wing and hind wing (linear regression analysis, fore wing; $p<0.001$, hind wing; $p<0.001)$.
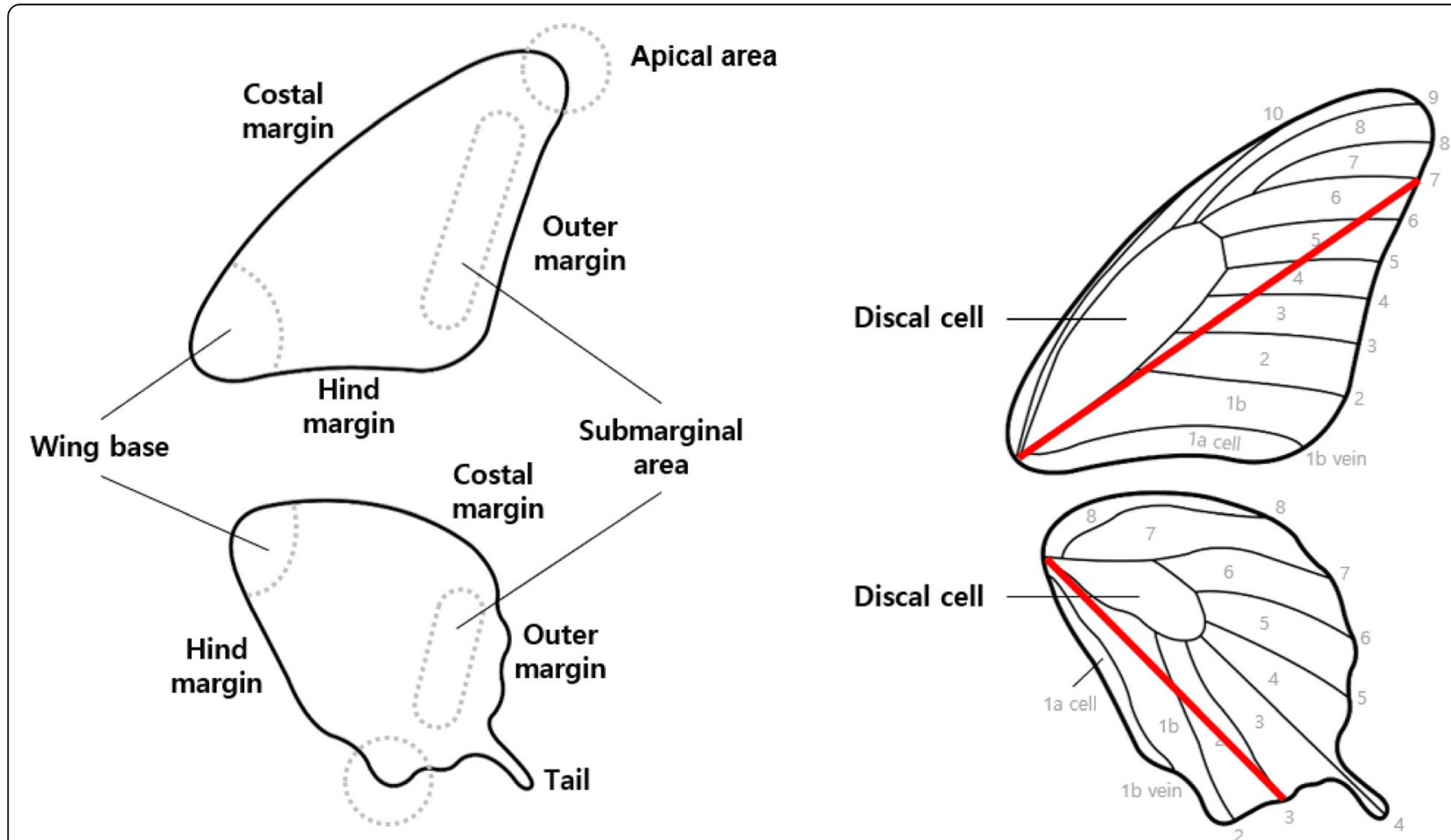

Tornal area

\section{A}

B

Fig. 1 Butterfly wing structure and standard of length measurement: A Structures and names of the fore and hind wings of butterflies. B The length of the fore wing was measured from the beginning of the fore wing to the tip of the seventh section, and the length of the hind wing was measured from the beginning of the hind wing to the third section. Reference: Coloured Butterfly of Korea (Shin 1991) 


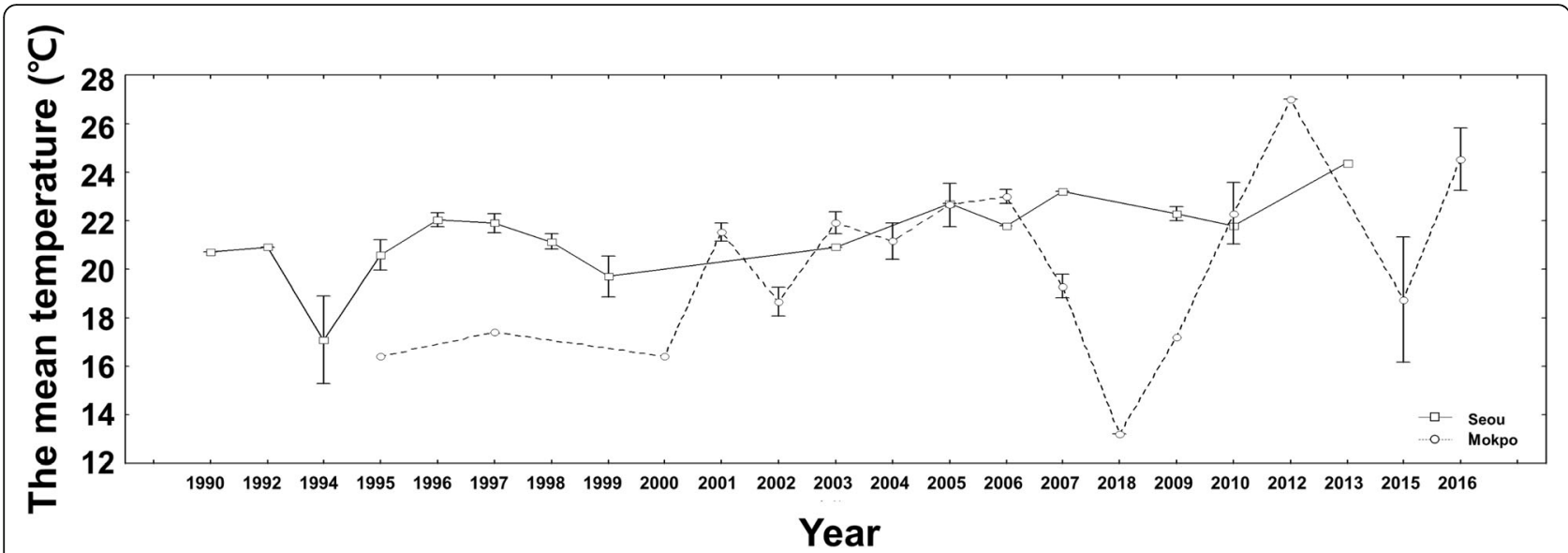

Fig. 2 Annual mean temperature and standard error in South Korea. Each mean temperature was computed by calculating the temperature of the date the butterfly was collected

In Papilionidae, the butterfly wing length increased with increasing mean temperature in A. alcinous in Seoul, $P$. macilentus in Seoul, P. macilentus in Mokpo, and P. stubbendorfii in Seoul except P. stubbendorfii in Mokpo.

In the case of the P. macilentus in Seoul was significantly increased in both fore wing and hind wing (linear regression analysis, fore wing; $p<0.001$, hind wing; $p<$ $0.01)$ and $P$. macilentus in Mokpo was significantly increased only hind wing (linear regression analysis, $p<$ 0.05). P. stubbendorfii in Mokpo was significantly decreased both of fore wing and hind wing (linear regression analysis, fore wing; $p<0.05$, hind wing; $p<0.05$ ).

In Pieridae, the butterfly wing length increased with increasing mean temperature in $C$. erate in Seoul, $P$. canidia in Seoul, P. dulcinea in Seoul, P. rapae in Seoul, but the butterfly wing length decreased with increasing mean temperature in $P$. canidia in Mokpo and $P$. rapae in Mokpo. In particular, P. dulcinea in Seoul was significantly increased both of fore wing and hind wing (linear regression analysis, fore wing; $p<0.01$, hind wing; $p<0.01$ ) (Fig. 3, Table 1).

For the whole butterfly species, regression analysis of the wing length was performed according to the temperature as shown in Table 2. As the temperature increased, the length of the butterfly wings also increased. Statistical analysis showed that the results were significantly increased (linear regression analysis, fore wing; $p$ $<0.01$, hind wing; $p<0.001$ ). The results of graphs of wing length according to temperature without distinction of species are shown in Fig. 4. As described above, the butterfly wing length increases with increasing temperature.

The mean wing length of individuals caught at the same temperature was plotted with temperature. In the case of P. c-aureum, P. macilentus, and P. dulcinea, the wing length increased with increasing temperature. On the other hand, the wing length of $P$. stubbendorfii tended to decrease with increasing temperature (Fig. 5, Table 3).

\section{Discussion}

In this study, we performed analysis to determine the relationship between the length of the butterfly wing and the mean temperature.

In case of annual mean temperature, it showed that the annual mean temperature is rising in both Seoul and Mokpo. Especially, Mokpo City's mean temperature is rising relatively steeply. This temperature increase is expected to have affected the growth of butterflies.

As the mean temperature increased in both of the regions, most of the wing length of butterflies seemed to increase. However, $P$. stubbendorfii, $P$. canidia, and $P$. rapae in Mokpo tend to decrease. Especially in case of $P$. stubbendorfii and P. canidia, it is presumed that more than $2 / 3$ of the specimens were collected on the same date and place. Samples collected at different times and diverse areas will be needed to obtain more accurate results.

According to a research conducted in the UK, the wing length of Hesperia comma is dependent upon temporal variation in summer temperatures. Previous studies have shown that June temperature affects the growth rate of butterflies, which is important for predicting adult size. Also, in the case of July, the temperature has a negative relationship with the time of emergence of adults. Finally, August temperatures are related to the range of behavior of butterflies (Phillip et al. 2016).

Therefore, studies evaluating the consequences of climate change on organisms with complex life cycles must 


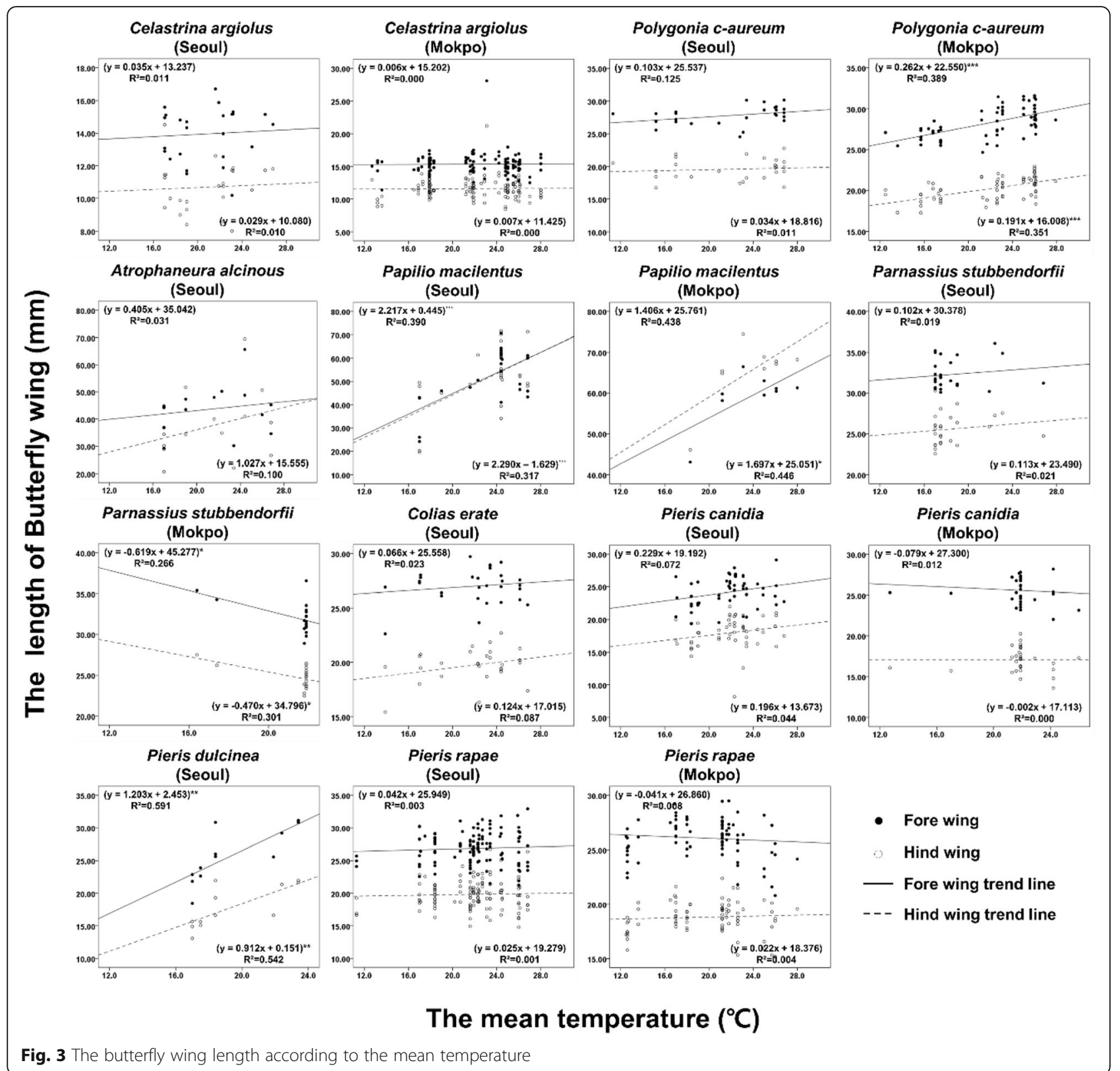

take into account the diverse responses of each life stage (Kingsolver et al. 2011).

Phillip et al. (2016)'s study was reported that the influence of temperature during particular life stages of $H$. comma, the target species of this study, is a univoltine and the life cycle is well-known. On the other hand, most of butterflies used in our study are multivoltine, and there is not much research on the life stage of butterfly species in Korea. Moreover, this study was conducted by using specimens; we analyzed the relationship between the butterflies which captured in the past and the temperature collected date. Therefore, comprehensive research considering life cycle is additionally needed in the future.

Analyzing the interactive effects of responses such as changes in body size, range seasonality, and range is a key and a step toward a comprehensive understanding

Table 2 Linear regression analysis of fore wing according to temperature of the whole butterfly species $\left({ }^{*} p<0.05,{ }^{* *} p<0.01,{ }^{* * *} p\right.$ $<0.001)$

\begin{tabular}{lllllll}
\hline & Fore wing & $\boldsymbol{R}^{2}$ & $\boldsymbol{p}$ value & Hind wing & $\boldsymbol{R}^{\mathbf{2}}$ & $\boldsymbol{p}$ value \\
\hline All species & $y=0.336 x+18.953$ & 0.018 & $* *$ & $y=0.410 x+11.357$ & 0.022 & $* * *$ \\
\hline
\end{tabular}




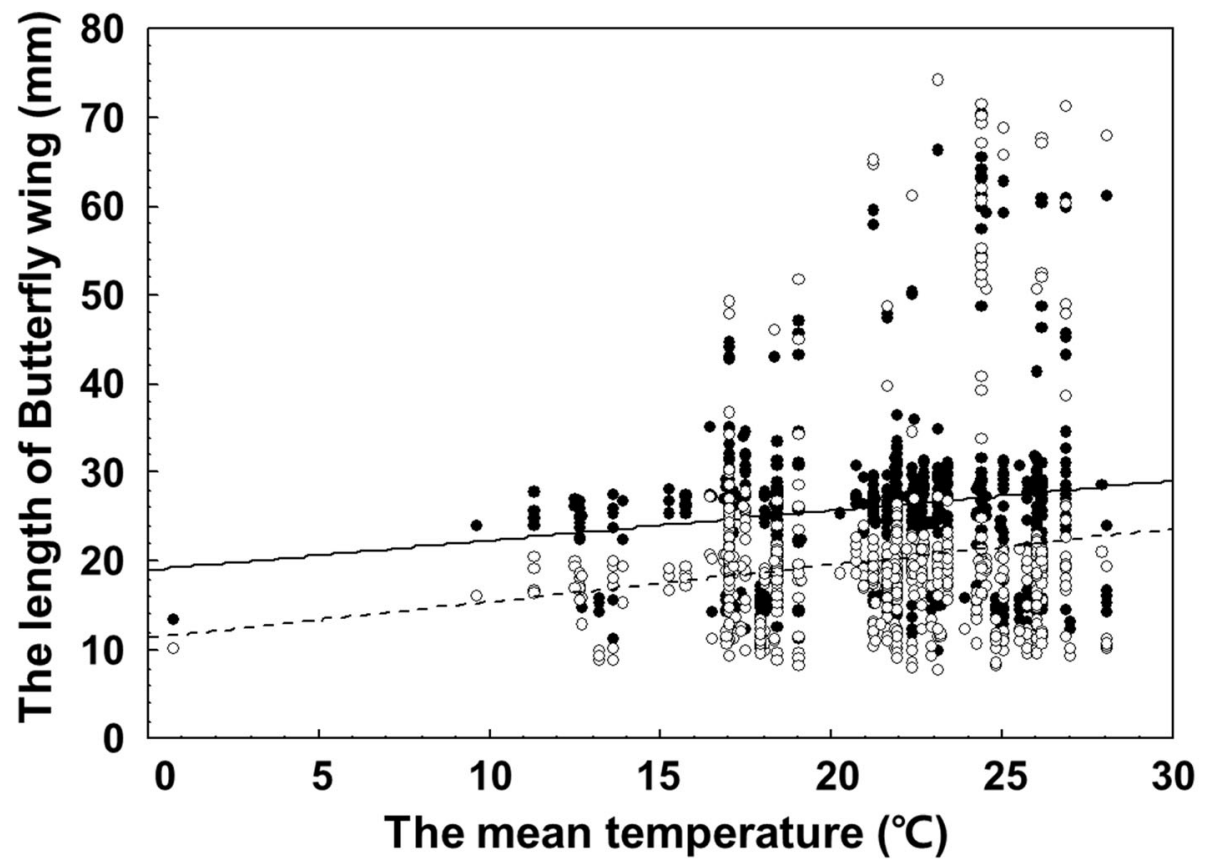

- Fore wing $\circ$ Hind wing

Fore wing trend line

Hind wing trend line

Fig. 4 Total butterfly wing length according to mean temperature

of the ecological impacts of climate change (Kingsolver et al. 2011; McCauley and Mabry 2011).

The impact of climate change on butterflies' habitats is reported around the world. However, there are few precedents for investigating morphological changes such as body size. In particular, there are no studies on this purpose that have been reported in Korea. The results of this study, together with previous studies, will enhance the possibility of butterfly as a climate indicator species.

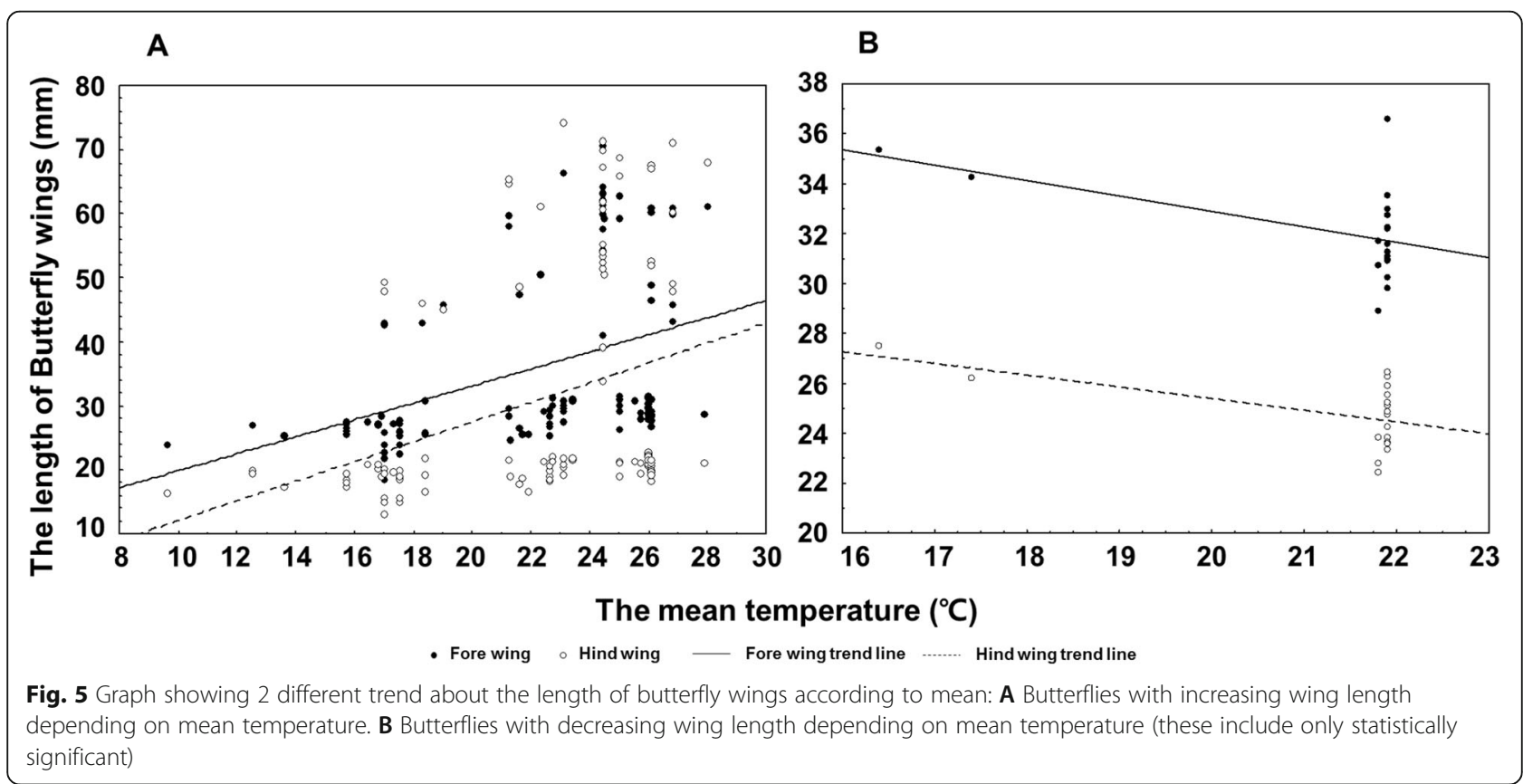


Table 3 Linear regression analysis of butterflies with increasing and decreasing wingspan depending on average temperature (this graph include only statistically significant, ${ }^{*} p<0.05,{ }^{* *} p<0.01,{ }^{* *} p<0.001$ )

\begin{tabular}{|c|c|c|c|c|c|c|c|}
\hline & Species & Fore wing & $R^{2}$ & $p$ value & Hind wing & $R^{2}$ & $p$ value \\
\hline Increase & $\begin{array}{l}\text { Polygonia c-aureum (Mokpo) } \\
\text { Papilio macilentus (Both) } \\
\text { Pieridae dulcinea (Seoul) }\end{array}$ & $y=1.326 x+6.628$ & 0.155 & $* * *$ & $y=1.540 x-3.290$ & 0.119 & $* * *$ \\
\hline Decrease & Parnassius stubbendorfii (Mokpo) & $y=-0.619 x+45.277$ & 0.266 & * & $y=-0.470 x+34.796$ & 0.301 & * \\
\hline
\end{tabular}

\section{Conclusion}

Several butterfly species are known exceptions to the TSR (temperature-size rule) (Atkinson 1994). In Jack et al. (2012)'s study, species of butterflies can see that the dry mass increases with increasing mean temperature. Also, Dennis and Shreeve (1989) found that the wingspan of adults of Hesperia comma was shortest at the northern edge of Scandinavia, where summer temperatures are cool.

These are consistent with the result of our study in which butterfly wing length and temperature have a positive relationship. Further research will be helpful in understanding the current situation of butterflies as according to climate change. The results of this study can be used as basic data for the study of the relationship between climate change and organisms.

\section{Abbreviation}

ASOS: Automated Surface Observing System

\section{Acknowledgements}

This work was supported by a research grant from Seoul Women's University (2021)

\section{Authors' contributions}

SMN analyzed data and reviewed the manuscript draft. EYL collected data and wrote the manuscript draft. HJK conceived the research idea and designed the study. SWC contributed to data collection. HBY supervised the research and reviewed the manuscript. All authors read and approved the final manuscript.

\section{Funding}

Funding was provided by the scholarship fund of the Seoul Women's University.

\section{Availability of data and materials}

The datasets used and/or analyzed during the current study are available from the corresponding author (Dr. Hoonbok Yi, yih@swu.ac.kr) on reasonable request.

\section{Declarations}

Ethics approval and consent to participate

Not applicable.

\section{Consent for publication}

Not applicable.

\section{Competing interests}

The authors declare that they have no competing interests.

\section{Author details}

'Department of Bio and Environmental Technology, Graduate School of Seoul Women's University, Seoul 01797, Republic of Korea. ${ }^{2}$ Department of Bio and Environmental Technology, Seoul Women's University, Seoul 01797,
Republic of Korea. ${ }^{3}$ Department of Environmental Education, Mokpo National University, Mokpo 58554, Republic of Korea.

Received: 8 March 2021 Accepted: 13 September 2021

Published online: 20 October 2021

\section{References}

Atkinson D. Temperature and organism size: a biological law for ectotherms. Adv Ecol Res. 1994;25:1-58. https://doi.org/10.1016/S0065-2504(08)60212-3.

Baudron A, Coby R, Needle L, Rijnsdorp AD, Marshall CT. Warming temperatures and smaller body sizes: synchronous changes in growth of North Sea fishes. Glob Change Biol. 2014;20(4):1023-31. https://doi.org/10.1111/gcb.12514.

Calder W. Size, function and life history. New York: Dover Publications; 1996.

Dennis, R. L. H., Shreeve, T. G. Butterfly wing morphology variation in the British Isles: the influence of climate, behavioural posture and the hostplant-habitat. Biological Journal of the Linnean Society. 1989;38(4):323-348.

DeLong JP, Gilbert B, Shurin JB, Savage VM, Barton BT, Clements CF, et al. The body size dependence of trophic cascades. Am Nat. 2015;185(3):354-66. https://doi.org/10.1086/679735.

Dingle HUGH, Khamala CP. Seasonal changes in insect abundance and biomass in an East African grassland with reference to breeding and migration in birds. Ardea. 1972;59:216-21.

Griffiths D. Size-abundance relations in communities. Am Nat. 1986;127(2):140-66. https://doi.org/10.1086/284475.

Honĕk A. Intraspecific variation in body size and fecundity in insects: a general relationship. Oikos. 1993;66(3):483-92. https://doi.org/10.2307/3544943.

IPCC. Climate change 2007: the physical science basis; 2007.

IPCC. Climate Change 2013: the physical science basis; 2013.

Jack F, Andrew GH, David A. Warming-induced reductions in body size are greater in aquatic than terrestrial species. PNAS. 2012;109(47):19310-4. https://doi.org/10.1073/pnas.1210460109.

Jeon H. Y. Change of butterfly distribution pattern in response to climate change in the Korean peninsula. The Graduate School Ewha Woman's University. 2014.

Jeong JC, Kim TK, Cha JY, Cho YH, Choi MJ, Nam SH. Sensitivity assessment and future directions of insect (butterfly) using climate change scenarios. Proc Korean Soc Appl Entomol Conf. 2012:14-4.

Kharouba HM, Paquette SR, Kerr JT, Vellend M. Predicting the sensitivity of butterfly phenology to temperature over the past century. Glob Change Biol. 2014;20(2):504-14. https://doi.org/10.1111/gcb.12429.

Kingsolver JG, Huey RB. Size, temperature, and fitness: three rules. Evol Ecol Res. 2008;10:251-68.

Kingsolver, J. G., Woods, H. A., Buckley, L. B., Potter, K., MacLean, H. J., Higgins, J. K. Complex life cycles and the responses of insects to climate change. Integrative and Comparative Biology. 2011;51:719-732.

Kiritani K. Predicting impacts of global warming on population dynamics and distribution of arthropods. Popul Ecol. 2006;48(1):5-12. https://doi.org/10.1 007/s10144-005-0225-0.

Kwon TS, Byun BK, Kang SH, Kim SS, Lee BW, Kim YK. Analysis on changes, and problems in phonology of butterflies in Gwangneung forest. Korean J Appl Entomol. 2008;47(3):209-16. https://doi.org/10.5656/KSAE.2008.47.3.209.

Lack PC. Diurnal and seasonal variation in biomass of arthropods in Tsavo East National Park, Kenya. Afr J Ecol. 1986;24(1):47-51. https://doi.org/10.1111/j.13 65-2028.1986.tb00341.x

Lee CK, Kwak KS, Kim JH, Son JY, Yang WH. Impacts of climate change and follow-up cropping season shift on growing period and temperature in different rice maturity types. Korean J Crop Sci. 2011;56(3):233-43. https://doi. org/10.7740/kjcs.2011.56.3.233

McCauley, S. J., Mabry, K. E. 2011. Climate change, body size, and phenotype 597 dependent dispersal. Trends in Ecology \& Evolution. 2011;26:554-555. 
NIMS (National Institute of Meteorological Sciences). Climate change over 100 years on the Korean Peninsula; 2018.

Paek MK, Shin YH. Butterflies of the Korean Peninsula: Nature and Ecology; 2010.

Parmesan C. Influences of species, latitudes and methodologies on estimates of phenological response to global warming. Glob Change Biol. 2007;13(9): 1860-72. https://doi.org/10.1111/j.1365-2486.2007.01404.x.

Peters RH. The ecological implications of body size: Cambridge University Press; 1983. https://doi.org/10.1017/CBO9780511608551.

Phillip BF, Angela S, John RS, Rebecca J, Stephen JB. Exploring the universal ecological responses to climate change in a univoltine butterfly. J Anim Ecol. 2016;85(3):739-48. https://doi.org/10.1111/1365-2656.12492.

Rautenbach IL, Kemp AC, Scholtz CH. Fluctuations in availability of arthropods correlated with microchiropteran and avian predator activities. KOEDOE. 1988:31(1):77-90. https://doi.org/10.4102/koedoe.v3111.486.

Russell TL, Lwetoijera DW, Knols BGJ, Takken W, Killeen GF, Ferguson HM. Linking individual phenotype to density-dependent population growth: the influence of body size on the population dynamics of malaria vectors. Proc $R$ Soc B Biol Sci. 2011;278(1721):3142-51. https://doi.org/10.1098/rspb.2011.0153.

Sheridan JA, Bickford D. Shrinking body size as an ecological response to climate change. Nat Climate Change. 2011;1(8):401-6. https://doi.org/10.1038/nclima te1259.

Shin Y-h. Coloured butterfly of Korea. Korea: Academy Publishing; 1991.

Siemann E, Tilman D, Haarstad J. Insect species diversity, abundance and body size relationships. Nature. 1996;380(6576):704-6. https://doi.org/10.1038/3 $80704 a 0$.

Stocker T. Climate change 2013: the physical science basis: Cambridge University Press; 2014

Trnka M, Muška F, Semerádováa D, Dunrovský M, Kocmánková E, Žalud Z. European corn borer life stage model: regional estimates of pest development and spatial distribution under present and future climate. Ecol Model. 2007;207(2-4):61-84. https://doi.org/10.1016/j.ecolmodel.2007.04.014.

Tseng M, Kaur KM, Pari SS, Sarai K, Chan D, Yao CH, et al. Decreases in beetle body size linked to climate change and warming temperatures. J Anim Ecol. 2017;87(3):647-59. https://doi.org/10.1111/1365-2656.12789.

White EP, Ernest SKM, Kerkhoff AJ, Enquist BJ. Relationships between body size and abundance in ecology. Trends Ecol Evol. 2007;22(6):323-30. https://doi. org/10.1016/j.tree.2007.03.007.

\section{Publisher's Note}

Springer Nature remains neutral with regard to jurisdictional claims in published maps and institutional affiliations.

Ready to submit your research? Choose BMC and benefit from:

- fast, convenient online submission

- thorough peer review by experienced researchers in your field

- rapid publication on acceptance

- support for research data, including large and complex data types

- gold Open Access which fosters wider collaboration and increased citations

- maximum visibility for your research: over $100 \mathrm{M}$ website views per year

At $\mathrm{BMC}$, research is always in progress.

Learn more biomedcentral.com/submissions 